DOI: 10.20472/IAC.2018.036.031

\author{
JOHN ADEBAYO OLOYEDE \\ EKITI STATE UNIVESITY, Nigeria \\ TOYIN OTAPO \\ ADEKUNLE AJASIN UNIVERSITY, , Nigeria \\ TOYIN OTAPO \\ ADEKUNLE AJASIN UNIVERSITY, Nigeria
}

\title{
TEST OF EXCHANGE MARKET EFFICIENCY IN NIGERIA
}

\begin{abstract}
:
This study investigated the foreign exchange market in Nigeria to determine the significance of past exchange rates in predicting the present exchange rates which is a test of weak form efficiency. It examined the cointegration between selected pairs of exchange rates to determine the semi strong form efficiency, and inspected the variant of the Random Walk Model that exchange rates in Nigeria conformed to. Secondary data sourced mainly from the Central Bank of Nigeria Statistical Bulletin 2014 and its official websites were used. The study's data were the spot and nominal monthly average foreign exchange rate series from the official market of Naira to Dollar, Naira to Pounds, Naira to Yen, Naira to Swiss Franc and Naira to CFA Franc between January, 1986 and December, 2015. Methods used include the autocorrellation function, unit root test and Johansen Cointegration test Autocorrelation and unit root tests revealed that all the series were non-stationary at level and became stationary at first difference. In addition, the Johansen cointegration test revealed that there were no cointegrating equations between selected pairs of exchange rates and the coefficients of determination were highest with the assumption of intercept and trend. The findings implied that the foreign exchange market in Nigeria within the sample period was efficient in the weak and semi strong forms, that is, information in past exchange rate series and public information were fully reflected in current exchange rates, the exchange rate series lacked exploitable pattern and conformed to the Random Walk Model with intercept and deterministic trend. The study therefore recommended that a more liberalized flexible exchange rate regime and improvements in money supply, national income, local and foreign bonds.
\end{abstract}

\section{Keywords:}

Exchange Market Efficiency, Nigeria foreign exchange market, Unit root, Cointegration, Granger causality test.

JEL Classification: E44 


\section{INTRODUCTION}

Market efficiency studies was pioneered by Fama (1965) who originally applied the concept to stock market prices. Application of the concept to foreign exchange market led to exchange market efficiency studies. The Efficient Market Hypothesis postulates that a market is efficient if all available information is reflected in the prices of the assets traded in such market thereby foreclosing the possibility of exploitable trends that can be used to outperform the market. As initially applied to stock prices, three notions of market efficiencies exist depending on the information set thus, Weak form, Semi Strong form and the Strong form (Wickremasinghe, 2004).

The concept of market efficiency has practical implications for the private sector and also to the government in formulating intervention policies in the exchange market. When the foreign exchange market is not efficient, there exist opportunities of making unusual or risk adjusted profits and private agents can formulate trading strategies to take advantage of such. Furthermore, present prices do not reflect all available information and forecasts of a forward rate based on the present non efficient rate can be outperformed by formulating a forward rate that can beat the future spot rate. A foreign exchange market that is not efficient presents a tantalizing profit making opportunity wished for by speculators. The government will interpret a non-efficient market as a market failure, that is failure of the market to set equilibrium prices and this translates into additional costs incurred by someone somewhere in form of greater unemployment, reduced output or higher prices and to correct this, government intervention policy is imperative.

An efficient market on the other hand means all available information are reflected in the quoted prices, out forecasting the market prices to earn unusual or risk adjusted profit will be difficult and private agents can concentrate on activities that reduce the risks of foreign exchange exposure. The incentive of engaging in forward transactions will not be to earn profit but to reduce risk exposure. To the public policy maker, the price in an efficient market is taken as the best reflection of information and conditions underlying the determination of exchange rates, intervention will be unnecessary and government agents can concentrate on addressing exogenous factors that determine the pattern of foreign exchange rates.

Conclusions of studies on financial market efficiency in the past can be categorized into two schools of thought thus, the Random walk School and the Time Series School. The Random Walk School holds the view that financial asset prices (stock prices, foreign exchange rates) follow a stochastic (random) path, thus past price movement cannot be used to predict future prices. Conversely, the Time Series School holds that financial asset prices follow a predictable path. In addition, inconsistencies have been noticed in past researches ranging from test methods, to conflicting results even with the same data set. For instance, (Wickremasinghe, 2004) concluded that the foreign exchange market of Sri Lanka was not efficient using Engen Granger cointegration test but concluded the opposite when he applied the Johansen's cointegration test. Kang (2008) applied a cointegration method known as the Search method which he claimed was better than the Ordinary least Square method in finding cointegration relationship, however, Reddy and Sebastin (2008) used a novel method called the entropic analysis in the Indian market. 
Reviewed works on foreign exchange market efficiency used mainly foreign data and were limited in spread and number of exchange rates used. In addition, where the market was found to be efficient, the specific model of random walk it conformed to was not located, (Wickremasinghe 2004, Lee and Sodoikhuu 2012, Aron 1997, and Mabakeng and Sheefeni 2014), while some tested the market efficiency in the forward foreign exchange market (Minalis 1995, Crowder 1994).

Nigerian studies that have foreign exchange rates as a variable examined the effect of exchange rate changes on indices of economic performance (Ayodele, 1988, Ogun, 1985). Of the very few exchange market efficiency studies by Nigerian scholars, Oloyede (1999) did a classification of exchange market efficiency studies which were mainly on foreign countries, one of his classifications is "test of time series properties of exchange rates, this paper seeked to provide empirical evidence of time series properties of exchange rates in Nigeria with a view to determining exchange market efficiency in the weak and semi strong forms.

The questions bothering on exchange market efficiency in Nigeria that were addressed in this study include: to what extent can past values of foreign exchange rate be used to predict current values? What is the nature of long run equilibrium relationship between selected pairs of foreign exchange rates? What is the nature of causality among various pairs of foreign exchange rates? And to what extent do series of currency exchange rates follow the Random Walk with intercept and trend?

The broad objective of this study is to determine the efficiency of spot foreign exchange market in Nigeria, while the specific objectives are to: determine the significance of past values of exchange rates in Nigeria in predicting present exchange rates in the country, evaluate whether selected pairs of foreign exchange rates have long run equilibrium relationship, investigate the causal relationship among selected pairs of foreign exchange rates in Nigeria and lastly, assess whether the series of exchange rates in Nigeria follow the Random Walk with intercept and trend Model.

The next section reviewed relevant literature while section three discussed research method. Section four contained results, discussions and recommendations and the paper was completed with conclusions and recommendations in section five.

\subsection{LITERATURE REVIEW}

\subsection{Conceptual literature}

The Efficient Market Hypothesis is concerned with the establishment of market prices and states that the prices of securities fully and fairly reflect all relevant available information (Fama, 1970). Market efficiency therefore refers to both the speed and the quality (direction and magnitude) of price adjustments to new information. Researchers have identified three forms of Market Efficiency thus: the weak form, the semi- strong form and the strong form efficiencies. A capital market is weak form efficient if the securities prices reflect all historical information such as past price volatility. In such a situation it will be impossible 
for a market player to use technical analysis to study past price movement, discover a trend and use such information to outperform the market or make unexpected profit. Infomation occur randomly as such price volatility to past information should also be random. Ibrahim, Long, Ghani and Mohd Salleh. (2011) stated that if a market is efficient in the weak form, it is impossible to predict future prices by analyzing past prices. Similarly, Fama (1970) defined the weak form efficiency as the situation in which the current prices reflect all information in the historic series of prices.

A market is semi strong form efficient if the prices reflects all past information and all publicly available information, and if prices react quickly and accurately to incorporate any new information as it becomes available. In a semi strong efficient market, an investor cannot use a company's financial statement to undertake a fundamental analysis and make abnormal returns. Fama (1970) defined it as a market in which current prices reflects all publicly available information. Publicly available information in this case includes past and emerging public information. A market is strong form efficient if its market price reflects all available information whether it is publicly available or not. It implies that even the investor with insider information cannot use such to make abnormal profit. According to Fama (1970), a market is strong form efficient if the current price reflects virtually all available information including proprietary and insider information. For instance, information such as proposed bonus share announcement or dividend payout are only known to top management initially before being made public. If such management staff leaks such insider information to a market player and makes abnormal gain, then the market is not strong form efficient. Researchers have widely reported that foreign exchange market are efficient in the weak and semi strong forms while widely not efficient in the strong form.

\subsection{Theoretical literature}

The theory of market efficiency was originally developed and applied to capital market. Its development was pioneered by Fama (1970), who defined an efficient market as a market where prices of its assets "fully reflect" all "available information". The term "fully reflect" suggests the existence of an equilibrium or benchmark to which actual prices conform. Fama (1970) further classified available information as historical, publicly available or insider coinciding with the weak form, semi strong form and strong form efficiencies respectively. Capital market efficiency theory has been widely applied to other financial markets including the foreign exchange market.

Conditions for market efficiency as established by Fama (1970) can be explained in terms of returns on assets or prices of financial assets. In terms of returns, if it is assumed that $r_{j, t+1}$ is the actual returns on assets $j$ at time $t+1$, and $E\left(r_{j, t+1}\right) / t_{t}$ is the expected returns based on available information set $I$ at time t. therefore excess returns will be.

$\mathrm{U}_{\mathrm{t}+1}=\mathrm{r}_{\mathrm{j}, \mathrm{t}+1}-\mathrm{E}\left(\mathrm{r}_{\mathrm{j}, \mathrm{t}+1) / \mathrm{lt}}\right.$

The conditions for market efficiency is that, the series $U_{t+1}$ on the average should equal to zero and secondly it must be free from serial correlation that is, it must conform to fair 
game. Existence of serial correlation in the series suggest the existence of a pattern that can be exploited for profit.

In terms of assets prices, the link between assets price today $\left(\mathrm{P}_{t}\right)$ and the expected future price given information set in time $t\left\{E\left(P_{t+1} / I_{t}\right)\right\}$, can be stated thus

$E\left(P_{t+1} / l_{t}\right)=P_{t}\left\{1+E\left(r_{t+1} / I_{t}\right\}\right.$

Where $E\left(r_{t+1} / l_{t}\right)$ is defined as the expected equilibrium rate of returns on spot market speculation. As in the case using returns, market efficiency requires that the excess of spot value of assets over expected values must conform to a fair game. That is

$\mathrm{U}_{\mathrm{t}+1}=\mathrm{P}_{\mathrm{t}+1}-\mathrm{E}\left(\mathrm{P}_{\mathrm{t}+1} / \mathrm{I}_{\mathrm{t}}\right)$

The International Fisher Effect under the assumption of uncovered interest parity has it that percentage expected exchange rate change equal percentage interest differential. (See equation 2.5 )

The study assumes $E\left(S_{t+1}\right)$ and $S_{t}$ as the expected spot rate in time $t+1$ and the current spot rate respectively, $I_{n}$ as the local interest rate and $I_{f}$ as the foreign interest rate. One Naira investment in Nigeria will earn $\left(1+i_{n}\right)$. If the one Naira is converted to foreign currency and invested abroad it will earn $1 / \mathrm{S}_{t}\left(1+l_{\mathrm{f}}\right)$, and if this is converted back to naira it becomes $1 / S_{t}\left(1+I_{f}\right) E\left(S_{t+1}\right)$. Investment in Nigeria and investment abroad will be similar, that is $\left(1+\mathrm{i}_{\mathrm{n}}\right) .=1 / \mathrm{S}_{\mathrm{t}}\left(1+\mathrm{If}_{\mathrm{f}}\right) \mathrm{E}\left(\mathrm{S}_{\mathrm{t}+1}\right)$

After deducting 1 from both sides of equation 2.4, it can be rewritten as

$\frac{E\left(s_{t+1}\right)-s_{t}}{s_{t}}=\frac{i_{n}-i_{f}}{1+i_{f}}$

That is

$E\left(S_{t+1}\right)=\left(1+i_{n}\right) /\left(1+i_{f}\right) \times S_{t}$

The international Fisher Effect tells us about the market's implied future spot rate and that if local interest rate is higher than foreign interest rate the exchange rate should be depreciating.

Equation 2.6 can also be rearranged as

$$
S_{t}=\frac{\left(1+i_{f}\right)}{1+i_{n}} \times E\left(s_{t+1}\right)=\frac{E\left(s_{t+1}\right)}{1+\left(i_{n-i_{f}}\right)}
$$

i.e $E\left(S_{t+1}\right)=S_{t}\left\{1+\left(i_{n}-i_{f}\right)\right\}$

Equation 2.8 means that the expected future spot rate is determined by the present spot rate and interest differentials between the countries under consideration.

Errors between expected and actual future spot rates is given as 


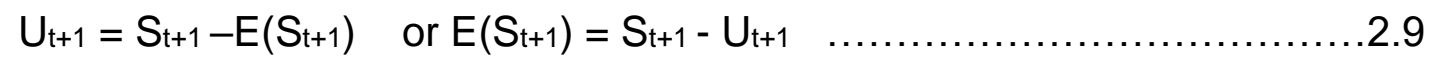

Equation 2.9 must be uncorrelated and equal to zero on the average (fair game) for the market to be efficient. Substituting the value of $E\left(S_{t+1}\right)$ in equation 2.9 thus
$S_{t+1}-U_{t+1}=S_{t}\left\{1+\left(i_{n}-i_{f}\right)\right\}$
$S_{t+1}-U_{t+1}=S_{t}+S_{t}\left(i_{n}-i_{f}\right)$ and
$\mathrm{S}_{\mathrm{t}+1}=\mathrm{S}_{\mathrm{t}}\left(\mathrm{i}_{\mathrm{n}}-\mathrm{i}_{\mathrm{f}}\right)+\mathrm{S}_{\mathrm{t}}+\mathrm{U}_{\mathrm{t}+1}$

Equation 2.12 conforms to the random walk model. If the value of $S_{t}\left(i_{n}-i_{f}\right)$ equals to zero (i.e where interest rate differentials equals to zero) it results into a situation of pure random walk, and if $S_{t}\left(i_{n}-i_{f}\right)$ is not equal to zero, it means a situation of random walk with drift.

\subsection{EMPIRICAL LITERATURE}

Dooley and Shafer (1976) used the filter rule on a sample of daily spot rates of nine currencies between 1973 and 1981. The data included the exchange rates of one United States dollars to the currencies of Belgium, Canada, France, Germany, Italy, Japan, Netherlands, Switzerland and the United Kingdom. They reported profitability for the small filters $(f=1,3$, Or 5 percent) while 50 per cent of the large filters $(10,15,20$ and 25$)$ reported profitability. Sweeney (1986) used the filter rule on a sample of ten currencies over the period April 1973 to December 1980 . He similarly reported profitability for small filters $(0.5$, $1,2,3,4,5$ and 10 percent). Schulmiester $(1987,1988)$ used three technical trading rules of Filter, Moving Average and the Momentum model on Dollar to Dutch Mark exchange rates between April 1973 and October 1986. He reported that over the period, the 2 percent filter achieved an average return of 8.2 percent which is statistically greater than zero; he also reported a positive but not statistically significant profitability for the one percent and three percent filters. On the contrary, the application of the moving average rule resulted into annual profits of 14- 15 percent which is statistically greater than zero.

Levich and Lee (1993) used the filter rule and the moving average crossover rule on a sample of 3800 daily currency futures prices between January 1976 and December 1990 involving the Dutch Mark, United Kingdom Dollar, Canadian Dollar, Yen and the Swiss franc. Profitability was similarly reported using the moving average and filter rules with the profitability of the latter being smaller. The profits are also lower for the Canadian Dollar which has lower volatility than the other currencies in the sample. They gauged the significance of the reported profits using the technical trading rule by testing the profitability of randomly generated series (obtained from the original series). It was observed that for most times the profits of the original series are greater than the profits from the randomly generated series.

Lee and Sodoikhuu (2012) applied the filter rules of buy long, sell short, to examine the efficiency of foreign market. Currencies examined were Euro dollars, Japanese Yen and Great Britain Pound. The sample period was between January 2, 2003 and December 30,2009 resulting into a sample size of 1713 . The authors reported that people will obtain 
more returns by taking long/sell short strategies of filter rule without considering transaction costs. But by considering transaction cost the result indicates that foreign exchange rate of the Eurodollars, Japanese Yen and Great Britain Pound will be more efficient.

Krishnavenni, Varadaraj and Karthika (2014) investigated the efficiency of the foreign exchange market using Random walk model. They adopted the serial correlation (Autocorrellation test) and the unit root test of Augmented Dickey Fuller (ADF). Daily rates of the CHFJPY for 5 years from $1^{\text {st }}$ January 2008 to $31^{\text {st }}$ December 2012 formed the sample. The overall autocorrelation of the currency pair from lag one to lag twenty was found to be significant at one percent level indicating lack of randomness in the first differences of the sample data. The authors concluded lack of weak form efficiency in respect of CHFJPY currency pair. Similarly the Augmented Dickey Fuller test rejected the hypothesis of the presence of unit root in the series and therefore concluded that the foreign exchange market is not efficient in the weak form for the currency pair of CHFJPY.

Ibrahim et al. (2011) examined the weak form efficiency of the foreign exchange market in thirty Organizations for Economic Cooperation and Development (OECD) countries using weekly data for the period 2000 to 2007. Data for spot, 3, 6, and 1 year forward were used, the writers conducted unit root tests using Augmented Dickey Fuller (ADF) Phillip- Peron (PP) and Kwiatkowski - Phillip-Schmidt-Shin (KPSS) tests. They found out that most variable are integrated of order one, 1(1), that is, they are non-stationary in the level but stationary in the first difference. This is consistent with the weak form of the Efficient Market Hypothesis.

Wickremasinghe (2004) conducted the weak form and the semi strong form efficiencies tests on Sri Lanka monthly data for six currencies for the period January 1986 to November 2000. The writer used Augmented Dickey Fuller and Phillip Peron tests for weak form and Johansen Cointegration, Granger Causality and Variance Decomposition analysis for the semi strong form tests. This researcher's unit root test concluded that all the six exchange rate are random walks in line with the Efficient Market Hypothesis $(E M H)$ in its weak form, but the semi strong form tests concluded that the market is not efficient.

Kasman and Ayhan (2007) investigated the relationship between exchange rates and foreign reserve using monthly data between 1982 and 2005. The Augmented Dickey Fuller (ADF), and Zivot and Andrews (1992) test of unit root were employed by them, they reported the absence of long run relationship between exchange rates and foreign exchange reserve. Kim and Ratti (2006) concluded a positive relationship between exchange rate and interest rate, similarly, Christos kollias et al. (2012) provided evidence of causality between the stock and exchange rate markets.

Ogun (1985) investigated how best to devalue the Naira and leans heavily on the Marshall Lerner condition that opines that devaluation will lead to an improvement in the trade balance if the sum of price elasticity of demand for devaluation sensitive exports and competitive imports plus the difference between the price elasticity of demand for noncompetitive imports in the total exceeds unity. He concluded that devaluation of Naira 
have bad effect on the Nigerian economy and by implication will reduce the welfare of Nigerians.

Ayodele (1988) examined the impact of exchange rate devaluation on the Nigerian external account using a model that regresses changes in foreign exchange rate on changes on foreign reserves, changes in capital and changes in current account balance. Research's sample data spans 1960 to 1985 . He concluded that a naira increase in foreign exchange rate has significant effects on foreign exchange reserve, capital balance and current account balance.

Oloyede (1999) did a review of existing literature and categorized existing empirical tests of exchange market efficiency into five groups thus, test of opportunity of making extra ordinary net income in the exchange market, test of ability of different technical trading rules (filter, moving average, and momentum) to produce abnormal profits, test of time series properties of foreign exchange rates and deviations from past forward rates. The other two categories are, test of forward exchange rates as predictors of future spot rates, and test of market forecasts of future foreign exchange rates. In addition the following more specific tests have been noticed in literature in recent times

i. Cointegration tests among various exchange rates in a country (Baillie and Bollerslev, 2014, Aron, 1997. Wickremasinghe, 2004.)

ii. Cointegration tests of exchange rates across various countries (Fama, 1984, Ibrahim et.al, 2011)

If two exchange rates cointegrate, one will be a predictor of the other, a violation of the semi strong form efficiency condition. This study investigated the time series properties of exchange rates in Nigeria to determine the weak form efficiency and examine the level of cointegration among selected pairs of foreign exchange rates in Nigeria to determine the semi strong form efficiency.

\subsection{RESEARCH METHOD}

\subsection{Model specification.}

The research adopts the Random Walk Model to test the stationarity of exchange rates as earlier used by Ibrahim et al. (2011) and Krishnaveni et al. (2014). The models are as follows.

Model I: Random walk without Drift

$Y_{t}=\beta_{2} Y_{t-1}+U_{i}$

Model II: Random Walk with Drift

$Y_{t}=\delta+\beta_{2} Y_{t-1}+U_{i}$

Model III: Random Walk with Drift and deterministic trend

$Y_{t}=\delta+\beta_{1} t+\beta_{2} Y_{t-1}+U_{i}$ 
Model IV: Cointegration Model

$Y=\alpha_{0}+\alpha_{1} X+U_{t}$

The author will also estimate

$U_{t}=P U_{t-1}$

\subsection{Variable description.}

In the Random Walk Models

$Y_{t}$ is the exchange rate in the current period

$\mathrm{Y}_{\mathrm{t}-1}$ is the exchange rate in the immediate past period

$\mathrm{t}$ is time, the trend parameter

$\sigma$ is the constant the drift parameter.

$\beta_{1}$ and $\beta_{2}$ are the coefficients

$U_{t}$ is the white noise error term with zero mean and constant variance.

In the cointegration model.

$\mathrm{X}$ and $\mathrm{Y}$ are any two stochastic variables (exchange rates of any two currencies) integrated of order one I(1).

$\alpha_{1}$ and $\alpha_{2}$ are the coefficients

$U_{t}$ is the white noise error term with zero mean and constant variance.

$\mathrm{U}_{\mathrm{t}-1}$ is the immediate past value of the error term

\subsection{Data source}

Secondary data sourced from the Central Bank of Nigeria Statistical Bulletin 2014 and its website (www.cbn.gov.ng/rates) were used in the study. The data represent the nominal official, monthly average foreign exchange rates in the Nigerian spot market. Five exchange rates, that is, the exchange rates of the Naira to five other international currencies will be involved in the study. The data period spans January 1986 to December 2015 , a period of thirty years. The monthly average rates for the period will result into a total sample of three hundred and sixty (360) for each of the five exchange rates making a total sample size of one thousand eight hundred (1800). The notion of market efficiency assumes market deregulation and minimum interventions from the government which was the exchange rate regime in Nigeria from 1986 when the floating exchange rate system was introduced in the country, this informed the choice of data period. Judgmental sampling technique based on listings in the Central Bank of Nigeria Statistical Bulletin was used to select the exchange rates, the specific five exchange rates include, Naira to US Dollar, 
Naira to Pounds Sterling, Naira to Japanese Yen, Naira to CFA Franc and Naira to Swiss Franc.

\subsection{Method of data analysis.}

Test of weak form efficiency in the foreign exchange market examines the significance of past values of exchange rates in determining their present values, this would be addressed by a test of stationarity of an equation that include the present and past values of exchange rates. The random walk model captures this scenario.

Popular tests of stationarity as identified by Gujarati (2013) include, graphical analysis, autocorrelation function (ACF) and correlogram; and unit root analysis. Gujarati (2013) also identified cointegration test as a test to determining whether two variables have a long term or equilibrium relationship. If two different exchange rates have long run or equilibrium relationship then one exchange rate can be used to predict the value of the other which is a necessary condition for the exchange market not to be semi strong form efficient. In addition, a popular test of causal relationship as identified by Cameron (2005) is the granger causality test. Unilateral or bilateral causal relationships between selected pairs of exchange rates are necessary violations of the semi strong form efficiency.

To test for the Weak form efficiency of the exchange market in Nigeria, the research used the Autocorrellation Function (ACF) and the unit root tests of Augmented Dickey Fuller (ADF) and Phillips Peron (PP). For the test of the semi strong form efficiency the Cointegration test (Kellard, 2006) and Causality test were adopted. In the Cointegration test the Johansen method were used. Lastly, in determining which of the Random walk models that the foreign exchange rates in Nigeria conform to, the coefficient of determination $\left(R^{2}\right)$ as contained in the unit root analysis were used to determine the model with the best fit. All the tests were carried out using the E-View statistical package.

\subsection{EMPIRICAL ANALYSES}

\subsection{Descriptive statistics:}

The summary of the descriptive is contained in table 4.1. The Pounds had the highest average at N136 to a Pound, a median of N160, a maximum of N307 and a minimum of N1.26. The CFA Franc had the lowest mean at N0.157, a median of N0.153, a maximum of 0.36 and a minimum of N0.006. The Pounds had the highest deviation from the mean at N104 while the CFA Franc had the lowest at N0.117. All the exchange rates had strong positive correlation with each other (table 4.2), that is, selected pairs had direct or positive relationship, for each pair, increase in one exchange rate led to an increase in the other. The pair of Dollars and Pounds had the highest correlation coefficient at 0.988 , while the pair of Pounds and Swiss Franc had the lowest at 0.948. The Covariance matrix summarized in table 4.3 depicts that the pair of Pounds and Swiss Franc had the highest covariability at 6500 , while the pair of CFA Franc and Yen had the lowest at 0.073 . The Pounds had the highest covariability with any other exchange rates. 
Table 4.1: Summary of Descriptive Statistics

\begin{tabular}{|l|l|l|l|l|l|}
\hline & $\begin{array}{l}\text { CFA } \\
\text { FRANC }\end{array}$ & DOLLARS & POUNDS & $\begin{array}{l}\text { SWISS } \\
\text { FRANC }\end{array}$ & YEN \\
\hline MEAN & 0.157 & 83.13 & 136.14 & 72.4 & .0 .799 \\
\hline MEDIAN & 0.153 & 106.7 & 160.73 & 65.52 & 0.938 \\
\hline MAXIMUM & 0.36 & 196.57 & 307.21 & 210.89 & 2.03 \\
\hline MINIMUM & 0.006 & 0.999 & 1.264 & 1.075 & 0.011 \\
\hline STD. DEV. & 0.117 & 63.39 & 104.05 & 63.19 & 0.647 \\
\hline
\end{tabular}

Source: Authors' computation (2016).

Table 4.2: Correlation Matrix

\begin{tabular}{|l|l|l|l|l|l|}
\hline & $\begin{array}{l}\text { CFA } \\
\text { FRANC }\end{array}$ & DOLLARS & POUNDS & $\begin{array}{l}\text { SWISS } \\
\text { FRANC }\end{array}$ & YEN \\
\hline CFA FRANC & 1 & 0.968 & 0.969 & 0.976 & 0.967 \\
\hline DOLLARS & 0.968 & 1 & 0.988 & 0.962 & 0.971 \\
\hline POUNDS & 0.969 & 0.988 & 1 & 0.949 & 0.952 \\
\hline $\begin{array}{l}\text { SWISS } \\
\text { FRANC }\end{array}$ & 0.975 & 0.964 & 0.949 & 1 & 0.968 \\
\hline YEN & 0.967 & 0.971 & 0.952 & 0.968 & 1 \\
\hline
\end{tabular}

Source: Authors' computation (2016).

Table 4.3: Covariance Matrix

\begin{tabular}{|l|l|l|l|l|l|}
\hline & $\begin{array}{l}\text { CFA } \\
\text { FRANC }\end{array}$ & DOLLARS & POUNDS & $\begin{array}{l}\text { SWISS } \\
\text { FRANC }\end{array}$ & YEN \\
\hline CFA FRANC & 0.014 & 7.174 & 11.797 & 7.210 & 0.073 \\
\hline DOLLARS & 7.174 & 4006.818 & 6500.1 & 3851.682 & 39.753 \\
\hline POUNDS & 11.797 & 6500.1 & 1079.5 & 6221.082 & 63.982 \\
\hline $\begin{array}{l}\text { SWISS } \\
\text { FRANC }\end{array}$ & 7.210 & 3851.682 & 6221.082 & 3982.246 & 39.467 \\
\hline YEN & 0.073 & 39.753 & 63.982 & 39.467 & 0.418 \\
\hline
\end{tabular}

Source: Authors' computation (2016).

\subsection{Results of analyses}

This section contained the result summaries of the tests for weak form efficiency using the Autocorrellation (ACF) test, the Unit Root tests using the Augmented Dickey Fuller (ADF) method as well as the Phillips-Perron method. It also contained the result summaries of the tests for Strong form efficiency which included the Johansen co-integration test and the Granger Causality test. 


\section{The autocorrelation function (ACF) test:}

The Autocorrelation Function and the $Q$ statistics for all the exchange rate series from lag 1 through lag 36 were presented in table 4.4 . The study applied the $95 \%$ confidence interval for Normal distribution and tested the hypothesis that $P_{k}$ (autocorrelation Function) was equal to Zero thus.

$P_{k}-1.96 X$ standard error $=Z=P_{k}+1.96 X$ standard error

Where $P_{k}$ is the Autocorrelation Function at lag $k$ and standard error is $\sqrt{1 / n}$ and $n$ is the sample size. Acceptance of the null hypothesis indicated that the series were stationary.

At level none of the interval from lag 1 through lag 36 contained the value zero, the study therefore rejected the null hypothesis (non- stationary). The Autocorrelation Function also approached zero as the lag length increased, this was similar to the property of Random Walk Process at level. However at first difference the intervals included the value zero, the researcher accepted the null hypothesis (stationary).

At level, the calculated $Q$ statistics were higher than the critical $Q$ statistics (55.8) obtained at 40 degrees of freedom and $5 \%$ level of significance using the Chi Square statistics. The study rejected the null hypothesis (non-stationary), but at first difference the calculated $Q$ statistics were lower than the critical $Q$ statistics, the null hypothesis was accepted (stationary). The Autocorrelation Function test revealed that the exchange rate series in Nigeria in the sample period were non-stationary at level but became stationary at first difference. This property followed the Random Walk Model.

Table 4.4: Autocorrelation Function Test Results at Level

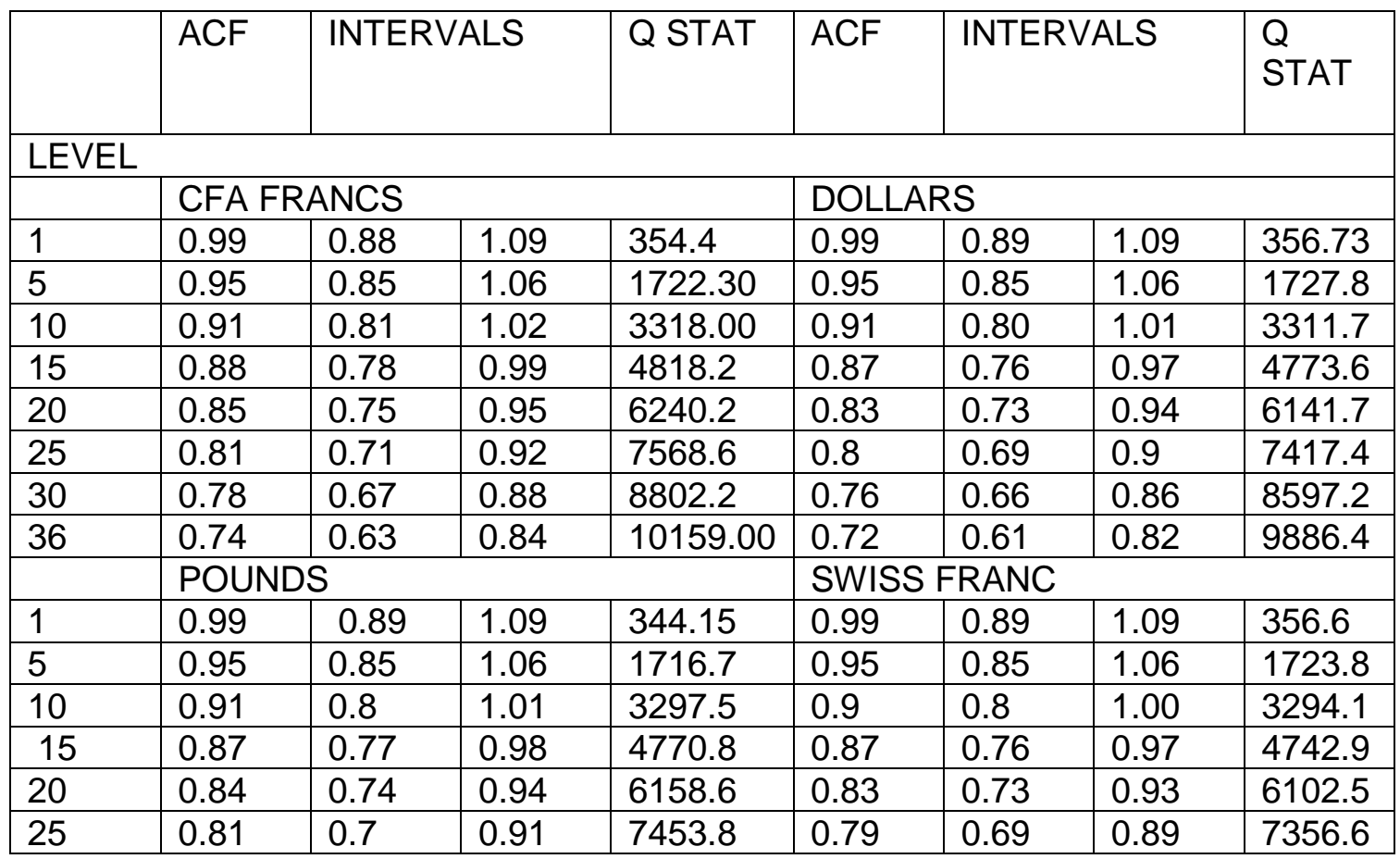




\begin{tabular}{|c|c|c|c|c|c|c|c|c|}
\hline 30 & 0.77 & 0.67 & 0.88 & 8861.9 & 0.75 & 0.65 & 0.85 & 8507.9 \\
\hline 36 & 0.73 & 0.63 & 0.84 & 10006.00 & 0.70 & 0.60 & 0.81 & 9760.9 \\
\hline & \multicolumn{4}{|l|}{ YEN } & & & & \\
\hline 1 & 0.99 & 0.89 & 1.09 & 356.21 & & & & \\
\hline 5 & 0.96 & 0.86 & 1.06 & 1734.20 & & & & \\
\hline 10 & 0.92 & 0.82 & 1.02 & 3355.80 & & & & \\
\hline 15 & 0.88 & 0.78 & 0.98 & 4863.20 & & & & \\
\hline 20 & 0.84 & 0.74 & 0.94 & 6261.30 & & & & \\
\hline 25 & 0.8 & 0.69 & 0.9 & 7542.70 & & & & \\
\hline 30 & 0.76 & 0.65 & 0.86 & 8715.40 & & & & \\
\hline 36 & 0.71 & 0.6 & 0.81 & 9988.00 & & & & \\
\hline
\end{tabular}

Source: Authors' computation (2016).

Table 4.4 Continues: Autocorrelation Function Test Result at First Difference

\begin{tabular}{|c|c|c|c|c|c|c|c|c|}
\hline & ACF & \multicolumn{2}{|c|}{ INTERVALS } & $\begin{array}{l}\mathrm{Q} \\
\text { STAT }\end{array}$ & ACF & \multicolumn{2}{|c|}{ INTERVALS } & $\begin{array}{l}\mathrm{Q} \\
\text { STAT }\end{array}$ \\
\hline \multicolumn{9}{|c|}{ FIRST DIFFERENCE } \\
\hline & \multicolumn{4}{|c|}{ CFA FRANCS } & \multicolumn{4}{|c|}{ DOLLARS } \\
\hline 1 & -0.24 & -0.34 & -0.13 & 20.33 & 0.07 & -0.03 & 0.17 & 1.71 \\
\hline 5 & -0.03 & -0.14 & 0.07 & 32.16 & -0.02 & -0.12 & 0.09 & 3.99 \\
\hline 10 & -0.04 & -0.15 & 0.06 & 34.16 & 0.01 & -0.1 & 0.11 & 4.29 \\
\hline 15 & -0.03 & -0.14 & 0.07 & 36.29 & -0.02 & -0.13 & 0.08 & 4.62 \\
\hline 20 & -0.01 & -0.11 & 0.1 & 40.27 & -0.01 & -0.11 & 0.09 & 5.47 \\
\hline 25 & -0.05 & -0.15 & 0.05 & 41.86 & -0.01 & -0.11 & 0.1 & 6.73 \\
\hline 30 & 0.00 & -0.11 & 0.10 & 43.99 & -0.03 & -0.13 & 0.07 & 7.83 \\
\hline \multirow[t]{2}{*}{36} & 0.01 & 0.09 & 0.11 & 44.69 & 0.00 & -0.10 & 0.11 & 8.13 \\
\hline & \multicolumn{4}{|c|}{ POUNDS } & \multicolumn{4}{|c|}{ SWISS FRANC } \\
\hline 1 & 0.03 & -0.07 & 0.13 & 0.35 & 0.10 & -0.1 & 0.2 & 3.4 \\
\hline 5 & -0.01 & -0.12 & 0.09 & 1.62 & -0.09 & 0.19 & 0.02 & 7.89 \\
\hline 10 & -0.01 & -0.12 & 0.09 & 4.74 & 0.07 & -0.03 & 0.18 & 13.64 \\
\hline 15 & 0.01 & -010 & 0.11 & 11.93 & -0.05 & -0.15 & 0.06 & 21.73 \\
\hline 20 & -0.04 & -0.14 & 0.06 & 18.59 & 0.03 & -0.08 & 0.13 & 26.68 \\
\hline 25 & -0.03 & -0.14 & 0.07 & 20.38 & -0.03 & -0.13 & 0.08 & 29.04 \\
\hline 30 & -0.03 & -0.13 & 0.08 & 21.13 & 0.01 & -0.09 & 0.11 & 29.66 \\
\hline \multirow[t]{2}{*}{36} & 0.01 & -0.09 & 0.12 & 22.38 & 0.07 & -0.04 & 0.17 & 41.06 \\
\hline & \multicolumn{4}{|l|}{ YEN } & & & & \\
\hline 1 & -0.16 & -0.26 & -0.05 & 8.68 & & & & \\
\hline 5 & -0.01 & -0.11 & 0.09 & 8.76 & & & & \\
\hline 10 & 0.03 & -0.08 & 0.13 & 40.16 & & & & \\
\hline 15 & 0.00 & -0.1 & 0.1 & 40.64 & & & & \\
\hline 20 & 0.04 & -0.06 & 0.15 & 41.77 & & & & \\
\hline 25 & 0.00 & -0.11 & 0.1 & 44.36 & & & & \\
\hline 30 & -0.02 & -0.12 & 0.08 & 46.01 & & & & \\
\hline 36 & -0.04 & -0.14 & 0.06 & 48.59 & & & & \\
\hline
\end{tabular}

Source: Authors' computation (2016). 


\section{Unit root test: the augmented dickey fuller (ADF) test.}

The study tested for the Null Hypothesis that the exchange rate series has a unit root at $5 \%$ level of significance. The test was conducted both at level and at first difference. The summaries of test results at level and first difference are presented in tables 4.5 and 4.6 respectively.

Table 4.4 Result Summary of Augmented Dickey Fuller Unit Root Test at Level

\begin{tabular}{|l|l|l|l|l|l|l|l|l|l|}
\hline & \multicolumn{3}{|c|}{$\begin{array}{c}\text { AUGMENTED } \\
\text { DICKEY FULLER } \\
\text { LEVEL } \\
\text { INTERCEPT } \\
\text { CRITICAL VALUE } \\
5 \%\end{array}$} & $\begin{array}{l}\text { AUGMENTED DICKEY } \\
\text { FULLER } \\
\text { LEVEL } \\
\text { INTERCEPT\&TREND } \\
\text { CRITICAL VALUE 5\% } \\
-3.422\end{array}$ & $\begin{array}{l}\text { AUGMENTED DICKEY } \\
\text { FULLER } \\
\text { LEVEL } \\
\text { NONE } \\
\text { CRITICAL VALUE 5\% } \\
-1.942\end{array}$ \\
\hline & $\begin{array}{l}\text { TEST } \\
\text { STAT }\end{array}$ & $\begin{array}{l}\mathrm{R}^{2} \\
(\%)\end{array}$ & DW & $\begin{array}{l}\text { TEST } \\
\text { STAT }\end{array}$ & $\begin{array}{l}\mathrm{R}^{2} \\
(\%)\end{array}$ & DW & $\begin{array}{l}\text { TEST } \\
\text { STAT }\end{array}$ & $\begin{array}{l}\mathrm{R}^{2} \\
(\%)\end{array}$ & DW \\
\hline $\begin{array}{l}\text { CFA } \\
\text { FRANC }\end{array}$ & $\begin{array}{l}-0.634 \\
\mathrm{a}\end{array}$ & 8.9 & 2.027 & $-2.657^{\mathrm{a}}$ & 10.6 & 2.018 & $1.094^{\mathrm{a}}$ & 8.2 & 2.02 \\
\hline $\begin{array}{l}\text { DOLLA } \\
\text { RS }\end{array}$ & $\begin{array}{l}0.071 \\
\mathrm{a}\end{array}$ & 0 & 1.862 & $-2.043^{\mathrm{a}}$ & 1.3 & 1.846 & 2.151 & 0 & 1.85 \\
\hline $\begin{array}{l}\text { POUND } \\
\text { S }\end{array}$ & $\begin{array}{l}-0.433 \\
\mathrm{a}\end{array}$ & 0 & 1.934 & $-2.166^{\mathrm{a}}$ & 1.3 & 1.918 & $1.372^{\mathrm{a}}$ & -0.6 & 1.93 \\
\hline $\begin{array}{l}\text { SWISS } \\
\text { FRANC }\end{array}$ & $0.650^{\mathrm{a}}$ & 0.1 & 1.811 & $-2.352^{\mathrm{a}}$ & 2 & 1.794 & 2.566 & -0.4 & 1.80 \\
\hline YEN & $\begin{array}{l}-0.803 \\
\mathrm{a}\end{array}$ & 2.5 & 2.008 & $-2.515^{\mathrm{a}}$ & 4.1 & 2.003 & 0.655 & 1.9 & 2.00 \\
\hline
\end{tabular}

Superscript 'a' indicates not significant, that is, non-stationary

Source: Authors' computation (2016).

At level, all the test statistics fell within the critical values except in two cases.Exceptions occurred where the Dollar and the Swiss Franc's test statistics fell outside the critical values under the assumption of pure Random Walk. The study therefore accepted the null hypothesis. The tests were not statistically significant and the series were non-stationary at level. However at first difference, all the test statistics were greater than the critical values, the null hypothesis was rejected, and the tests were statistically significant, that is, the series were stationary at first difference. 


\section{Table 4.6: Result Summary Augmented Dickey Fuller Unit Root Test at First Difference}

\begin{tabular}{|c|c|c|c|c|c|c|c|c|c|}
\hline & \multicolumn{3}{|c|}{$\begin{array}{c}\text { AUGMENTED } \\
\text { DICKEY FULLER } \\
\text { FIRST DIFFERENCE } \\
\text { INTERCEPT } \\
\text { CRITICAL VALUE 5\% } \\
-2.869\end{array}$} & \multicolumn{3}{|c|}{$\begin{array}{c}\text { AUGMENTED DICKEY } \\
\text { FULLER } \\
\text { FIRST DIFFERENCE } \\
\text { INTERCEPT\&TREND } \\
\text { CRITICAL VALUE 5\% } \\
-3.422\end{array}$} & \multicolumn{3}{|c|}{$\begin{array}{l}\text { AUGMENTED DICKEY } \\
\text { FULLER } \\
\text { FIRST DIFFERENCE } \\
\text { NONE } \\
\text { CRITICAL VALUE } 5 \% \\
-1.942\end{array}$} \\
\hline & $\begin{array}{l}\text { TEST } \\
\text { STAT }\end{array}$ & $\begin{array}{l}R^{2} \\
(\%)\end{array}$ & DW & $\begin{array}{l}\text { TEST } \\
\text { STAT }\end{array}$ & $\begin{array}{l}R^{2} \\
(\%)\end{array}$ & DW & $\begin{array}{l}\text { TEST } \\
\text { STAT }\end{array}$ & $\begin{array}{l}R^{2} \\
(\%)\end{array}$ & DW \\
\hline $\begin{array}{l}\text { CFA } \\
\text { FRANC }\end{array}$ & -17.811 & 63 & 2.02 & -17.787 & 63 & 2.02 & -17.657 & 62.8 & 2.023 \\
\hline DOLLARS & -17.612 & 46.6 & 2 & -17.611 & 46.6 & 2 & -17.319 & 45.6 & 2 \\
\hline POUNDS & -18.210 & 48.4 & 2 & -18.187 & 48.4 & 2 & -18.035 & 47.9 & 2 \\
\hline $\begin{array}{l}\text { SWISS } \\
\text { FRANC }\end{array}$ & -17.113 & 45.1 & 2 & -17.166 & 45.4 & 2 & -16.793 & 44.1 & 2.01 \\
\hline YEN & -22.05 & 57.7 & 2.01 & -22.025 & 57.7 & 2.01 & -21.967 & 57.4 & 2.01 \\
\hline
\end{tabular}

Source: Authors' computation (2016).

The Coefficient of Determination $\mathrm{R}^{2}$ in tables 4.5 and 4.6 were highest under the assumption of Random Walk with intercept and Deterministic Trend. This led to the conclusion that the Nigerian exchange rate series in the sample period followed the Random Walk with Intercept and deterministic trend model.

\section{Unit root tests: phillips-perron}

The summaries of test results were contained in tables 4.7 and 4.8 . The study tested for the Null hypothesis that the exchange rate series had a unit root at $5 \%$ level of significance. The tests were conducted at level (table 4.7) and at first difference (table 4.8). At level, almost all the test statistics fell within the critical values, the null hypothesis was therefore accepted, the tests were not statistically significant and the series were non-stationary. However two cases where the series were stationary at level were noticed, these were in the case of CFA Franc under the assumption of only intercept and the Swiss Franc under the assumption of Pure Random Walk

Conversely, at first difference the test statistics were greater than the critical values in all the cases. The null hypothesis was rejected, the tests were significant and the series were stationary. The coefficient of determination $\mathrm{R}^{2}$ was also highest under the assumption of intercept and trend. This pointed to the fact that the exchange rate series in Nigeria followed the Random Walk with intercept and deterministic trend. 
Table 4.7: Result Summary of Phillips-Perron Unit Root Test at Level

\begin{tabular}{|c|c|c|c|c|c|c|c|c|c|}
\hline & \multicolumn{3}{|c|}{$\begin{array}{c}\text { PHILLIPS- PERRON } \\
\text { LEVEL } \\
\text { INTERCEPT } \\
\text { CRITICAL VALUE } \\
5 \% \\
-2.869\end{array}$} & \multicolumn{3}{|c|}{$\begin{array}{c}\text { PHILLIPS-PERRON } \\
\text { LEVEL } \\
\text { INTERCEPT\&TREND } \\
\text { CRITICAL VALUE 5\% } \\
-3.422\end{array}$} & \multicolumn{3}{|c|}{$\begin{array}{l}\text { PHILLIPS-PERRON } \\
\text { LEVEL } \\
\text { NONE } \\
\text { CRITICAL VALUE } 5 \% \\
-1.942\end{array}$} \\
\hline & $\begin{array}{l}\text { TEST } \\
\text { STAT }\end{array}$ & $\begin{array}{l}\mathrm{R}^{2} \\
(\%)\end{array}$ & DW & $\begin{array}{l}\text { TEST } \\
\text { STAT }\end{array}$ & $\begin{array}{l}R^{2} \\
(\%)\end{array}$ & DW & $\begin{array}{l}\text { TEST } \\
\text { STAT }\end{array}$ & $\begin{array}{l}\mathrm{R}^{2} \\
(\%)\end{array}$ & DW \\
\hline $\begin{array}{l}\text { CFA } \\
\text { FRANC }\end{array}$ & $-0.808^{a}$ & 0.3 & $\begin{array}{l}2.46 \\
5\end{array}$ & -3.486 & 4.1 & $\begin{array}{l}2.37 \\
6\end{array}$ & $0.750^{a}$ & -0.3 & 2.470 \\
\hline $\begin{array}{l}\text { DOLLAR } \\
\text { S }\end{array}$ & $\begin{array}{l}-0.0473 \\
a\end{array}$ & 0 & $\begin{array}{l}1.86 \\
2\end{array}$ & $-2.67^{a}$ & 1.3 & $\begin{array}{l}1.84 \\
6\end{array}$ & $1.874^{\mathrm{a}}$ & -0.7 & 1.857 \\
\hline POUNDS & $-0.486^{a}$ & 0 & $\begin{array}{l}1.93 \\
8\end{array}$ & $-2.344^{a}$ & 1.3 & $\begin{array}{l}1.91 \\
8\end{array}$ & $1.222^{a}$ & -0.6 & 1.933 \\
\hline $\begin{array}{l}\text { SWISS } \\
\text { FRANC }\end{array}$ & $0.475^{a}$ & 0.1 & $\begin{array}{l}1.81 \\
1\end{array}$ & $-2.493^{a}$ & 2 & $\begin{array}{l}1.79 \\
4\end{array}$ & 2.233 & -0.4 & 1.807 \\
\hline YEN & $-0.809^{a}$ & 0.2 & $\begin{array}{l}2.30 \\
3\end{array}$ & $-2.686^{a}$ & 2.3 & 2.25 & $0.642^{a}$ & -0.4 & 2.303 \\
\hline
\end{tabular}

Superscript 'a' indicates acceptance of the null hypothesis

Source: Authors' computation (2016).

Table 4.8 Result Summary of Phillips- Perron Unit Root test at First Difference

\begin{tabular}{|c|c|c|c|c|c|c|c|c|c|}
\hline & \multicolumn{3}{|c|}{$\begin{array}{c}\text { PHILLIPS- PERRON } \\
\text { FIRST DIFFERENCE } \\
\text { INTERCEPT } \\
\text { CRITICAL VALUE } \\
5 \% \\
-2.869\end{array}$} & \multicolumn{3}{|c|}{$\begin{array}{l}\text { PHILLIPS-PERRON } \\
\text { FIRST DIFFERENCE } \\
\text { INTERCEPT\&TREND } \\
\text { CRITICAL VALUE 5\% } \\
-3.422\end{array}$} & \multicolumn{3}{|c|}{$\begin{array}{l}\text { PHILLIPS-PERRON } \\
\text { FIRST DIFFERENCE } \\
\text { NONE } \\
\text { CRITICAL VALUE 5\% } \\
-1.942\end{array}$} \\
\hline & $\begin{array}{l}\text { TEST } \\
\text { STAT }\end{array}$ & $\begin{array}{l}R^{2} \\
(\%)\end{array}$ & DW & $\begin{array}{l}\text { TEST } \\
\text { STAT }\end{array}$ & $R^{2}(\%$ & DW & $\begin{array}{l}\text { TEST } \\
\text { STAT }\end{array}$ & $(\%) R^{2}$ & DW \\
\hline $\begin{array}{l}\text { CFA } \\
\text { FRANC }\end{array}$ & -24.727 & 61.8 & $\begin{array}{l}2.08 \\
7\end{array}$ & -24.690 & 61.8 & $\begin{array}{l}2.0 \\
8\end{array}$ & -24.746 & 61.6 & 2.081 \\
\hline $\begin{array}{l}\text { DOLLAR } \\
\mathrm{S}\end{array}$ & -17.659 & 46.5 & 2 & -17.656 & 46.6 & 2 & -17.468 & 45.6 & 2 \\
\hline POUNDS & -18.234 & 48.4 & 2 & -18.212 & 48.4 & 2 & -18.096 & 47.9 & 2 \\
\hline $\begin{array}{l}\text { SWISS } \\
\text { FRANC }\end{array}$ & -17.153 & 45.1 & 2 & -17.167 & 45.3 & 2 & -16.786 & 44.1 & 2.01 \\
\hline YEN & -22.123 & 57.7 & 2 & -22.092 & 57.7 & 2 & -21.998 & 57.5 & 2 \\
\hline
\end{tabular}

Source: Authors' computation (2016). 


\section{Johansen cointegration test}

A necessary condition for the conduct of cointegration test is that the selected pairs of exchange rate series must be integrated of same order. Since all the series became stationary (integrated) at first difference all the exchange rate series qualified to be included in the pairwise cointegration analysis. For each pair, the researcher tested the null hypothesis of no cointegrating equation at $5 \%$ level of significance. The trace statistics and the maximum Eigen statistics under the trend assumption of linear deterministic trend were employed. The trace statistics as well as the Maximum Eigen statistics were all within the respective critical values. The study therefore accepted the null hypothesis, that is, the test was not statistically significant and none of the selected pairs were cointegrated. The summary of Johansen cointegration test result is contained in table 4.8

Table 4.9 Result Summary of Johansen Cointegration Test.

\begin{tabular}{|l|l|l|l|l|}
\hline & TRACE STAT & $\begin{array}{l}\text { CRITICAL } \\
\text { VALUE }\end{array}$ & $\begin{array}{l}\text { MAX EIGEN } \\
\text { VALUE }\end{array}$ & $\begin{array}{l}\text { CRITICAL } \\
\text { VALUE }\end{array}$ \\
\hline CFA/DOLLARS & 5.879 & 15.495 & 5.856 & 14.265 \\
\hline CFA/POUNDS & 5.194 & 15.495 & 4.677 & 14.265 \\
\hline CFA/SWISS FRANC & 4.782 & 15.495 & 4.772 & 14.265 \\
\hline CFA/YEN & 7.774 & 15.495 & 7.384 & 14.265 \\
\hline DOLLARS/POUNDS & 10.07 & 15.495 & 10.05 & 14.265 \\
\hline $\begin{array}{l}\text { DOLLARS/SWISS } \\
\text { FRANC }\end{array}$ & 3.831 & 15.495 & 3.798 & 14.265 \\
\hline DOLLARS/YEN & 3.264 & 15.495 & 3.263 & 14.265 \\
\hline $\begin{array}{l}\text { POUNDS/SWISS } \\
\text { FRANC }\end{array}$ & 3.411 & 15.495 & 3.397 & 14.265 \\
\hline POUNDS/YEN & 4.539 & 15.495 & 4.121 & 14.265 \\
\hline SWISSFRANC/YEN & 4.646 & 15.495 & 4.646 & 14.265 \\
\hline
\end{tabular}

For all the pairs, null hypothesis was accepted, i.e. pairs were not cointegrated. Test was not significant.

Source: Authors' computation (2016).

\section{Granger causality test}

As in the case of cointegration test, a condition for performing Granger causality test is that the selected pairs of exchange rate series are integrated of same order. All the exchange rate series used in the study were stationary at first difference, that is, they were integrated of order I(1), therefore all the series were involved in the causality test. The critical $F$ statistics were obtained at $5 \%$ level of significance at $k-1\left(V_{1}\right)$ and $n-K\left(V_{2}\right)$ degrees of freedom. $\mathrm{K}$ is the number of variables and $\mathrm{n}$ is the sample size. The critical $\mathrm{F}$ statistics at $(1,358)\left(V_{1}, V_{2}\right)$ was approximately 3.84. The summary of the Granger Causality test results is contained in table 4.10. In majority of the cases the researcher accepted the null hypothesis of no causal relationship between the pairs, that is, the tests were not 
significant. However, the hypothesis that Yen does not Granger cause CFA Franc is mainly statistically significant, that is rejection of the Null Hypothesis. A case of unidirectional causality from Yen to CFA Franc was established. In addition the calculated F statistics decayed as the lag length increased. This meant that past exchange rates in near periods had more causal effect on present exchange rates than far periods' past rates. The farther the period the lower the causal effect

Table 4.10. F statistics of Pairwise Granger Causality Test

\begin{tabular}{|c|c|c|c|c|c|c|c|c|c|c|c|c|c|c|c|c|c|c|c|c|}
\hline & $A$ & B & C & $\mathrm{D}$ & $\mathrm{E}$ & $\mathrm{F}$ & $\mathrm{G}$ & $\mathrm{H}$ & 1 & $\mathrm{~J}$ & $\mathrm{~K}$ & $\mathrm{~L}$ & $M$ & $\mathrm{~N}$ & 0 & $P$ & $Q$ & $\mathrm{R}$ & $S$ & $\mathrm{~T}$ \\
\hline Lag & & & & & & & & & & & & & & & & & & & & \\
\hline 2 & $\begin{array}{l} \\
8\end{array}$ & $\begin{array}{l}0 . \\
6 \\
a\end{array}$ & $\begin{array}{l}8 . \\
6\end{array}$ & $\begin{array}{l}0 . \\
7 \\
\mathrm{a}\end{array}$ & $\begin{array}{l}7 . \\
5\end{array}$ & $\begin{array}{l}0 . \\
6 \\
\mathrm{a}\end{array}$ & $\begin{array}{l}5 . \\
1\end{array}$ & $\begin{array}{l}2 . \\
1 \\
a\end{array}$ & $\begin{array}{l}1 . \\
6 \\
a\end{array}$ & $\begin{array}{l}4 . \\
2\end{array}$ & $\begin{array}{l}1 . \\
1 \\
a\end{array}$ & $\begin{array}{l}0 . \\
9 \\
a\end{array}$ & $\begin{array}{l}0 . \\
4 \\
\mathrm{a}\end{array}$ & $\begin{array}{l}6 . \\
4\end{array}$ & $\begin{array}{l}0 . \\
2 \\
a\end{array}$ & $\begin{array}{l}0 . \\
1 \\
a\end{array}$ & $\begin{array}{l}0 . \\
5 \\
a\end{array}$ & $\begin{array}{l}3 . \\
9\end{array}$ & $\begin{array}{l}0 . \\
2 \\
a\end{array}$ & 4. \\
\hline 3 & $\begin{array}{l}5 . \\
3\end{array}$ & $\begin{array}{l}0 . \\
7 \\
\mathrm{a}\end{array}$ & $\begin{array}{l}8 . \\
6\end{array}$ & $\begin{array}{l}0 . \\
6 \\
a\end{array}$ & $\begin{array}{l}8 . \\
1\end{array}$ & $\begin{array}{l}0 . \\
4 \\
\mathrm{a}\end{array}$ & $\begin{array}{l}4 . \\
6\end{array}$ & $\begin{array}{l}1 . \\
6 \\
a\end{array}$ & $\begin{array}{l}1 . \\
9 \\
a\end{array}$ & $\begin{array}{l}2 . \\
9 \\
a\end{array}$ & $\begin{array}{l}0 . \\
9 \\
\mathrm{a}\end{array}$ & $\begin{array}{l}0 . \\
8 \\
a\end{array}$ & $\begin{array}{l}0 . \\
5 \\
\mathrm{a}\end{array}$ & $\begin{array}{l}4 . \\
5\end{array}$ & $\begin{array}{l}0 . \\
4 \\
a\end{array}$ & $\begin{array}{l}0 . \\
2 \\
a\end{array}$ & $\begin{array}{l}1 \\
a\end{array}$ & $\begin{array}{l}2 . \\
8 \\
a\end{array}$ & $\begin{array}{l}0 . \\
3 \\
a\end{array}$ & $\begin{array}{l}3 . \\
2 \\
\mathrm{a}\end{array}$ \\
\hline 4 & $\begin{array}{l}5 . \\
0\end{array}$ & $\begin{array}{l}0 . \\
6 \\
a\end{array}$ & $\begin{array}{l}8 . \\
2\end{array}$ & $\begin{array}{l}0 . \\
8 \\
a\end{array}$ & $\begin{array}{l}8 . \\
4\end{array}$ & $\begin{array}{l}0 . \\
5 \\
a\end{array}$ & $\begin{array}{l}4 . \\
8\end{array}$ & $\begin{array}{l}1 . \\
3 \\
a\end{array}$ & $\begin{array}{l}1 . \\
7 \\
\mathrm{a}\end{array}$ & $\begin{array}{l}2 . \\
2 \\
a\end{array}$ & $\begin{array}{l}0 . \\
7 \\
\mathrm{a}\end{array}$ & $\begin{array}{l}0 . \\
7 \\
\mathrm{a}\end{array}$ & $\begin{array}{l}0 . \\
4 \\
\mathrm{a}\end{array}$ & $\begin{array}{l}3 . \\
4 \\
a\end{array}$ & $\begin{array}{l}0 . \\
3 \\
a\end{array}$ & $\begin{array}{l}0 . \\
2 \\
a\end{array}$ & $\begin{array}{l}0 . \\
8 \\
a\end{array}$ & $\begin{array}{l}2 . \\
2 \\
a\end{array}$ & $\begin{array}{l}0 . \\
3 \\
a\end{array}$ & $\begin{array}{l}2 . \\
5 \\
a\end{array}$ \\
\hline 5 & $\begin{array}{l}3 . \\
7 \\
a\end{array}$ & $\begin{array}{l}0 . \\
7 \\
a\end{array}$ & $\begin{array}{l}5 . \\
7\end{array}$ & $\begin{array}{l}0 . \\
6 \\
a\end{array}$ & $\begin{array}{l}6 . \\
1\end{array}$ & $\begin{array}{l}0 . \\
4 \\
\mathrm{a}\end{array}$ & $\begin{array}{l}3 . \\
7 \\
a\end{array}$ & $\begin{array}{l}1 . \\
1 \\
a\end{array}$ & $\begin{array}{l}1 . \\
8 \\
a\end{array}$ & $\begin{array}{l}1 . \\
8 \\
a\end{array}$ & $\begin{array}{l}0 . \\
8 \\
a\end{array}$ & $\begin{array}{l}0 . \\
8 \\
a\end{array}$ & $\begin{array}{l}0 . \\
4 \\
\mathrm{a}\end{array}$ & $\begin{array}{l}2 . \\
7 \\
a\end{array}$ & $\begin{array}{l}0 . \\
4 \\
a\end{array}$ & $\begin{array}{l}0 . \\
2 \\
a\end{array}$ & $\begin{array}{l}0 . \\
7 \\
\mathrm{a}\end{array}$ & $\begin{array}{l}1 . \\
9 \\
a\end{array}$ & $\begin{array}{l}0 . \\
4 \\
a\end{array}$ & $\begin{array}{l}2 . \\
4 \\
a\end{array}$ \\
\hline 6 & $\begin{array}{l}3 . \\
1 \\
\text { a }\end{array}$ & $\begin{array}{l}0 . \\
8 \\
a\end{array}$ & $\begin{array}{l}4 . \\
8\end{array}$ & $\begin{array}{l}0 . \\
5 \\
a\end{array}$ & $\begin{array}{l}5 . \\
1\end{array}$ & $\begin{array}{l}0 . \\
4 \\
\mathrm{a}\end{array}$ & $\begin{array}{l}3 . \\
1 \\
a\end{array}$ & $\begin{array}{l}0 . \\
9 \\
\mathrm{a}\end{array}$ & $\begin{array}{l}1 . \\
5 \\
a\end{array}$ & $\begin{array}{l}1 . \\
6 \\
a\end{array}$ & $\begin{array}{l}0 . \\
8 \\
a\end{array}$ & $\begin{array}{l}1 \\
a\end{array}$ & $\begin{array}{l}0 . \\
4 \\
\mathrm{a}\end{array}$ & $\begin{array}{l}2 . \\
3 \\
a\end{array}$ & $\begin{array}{l}0 . \\
4 \\
\mathrm{a}\end{array}$ & $\begin{array}{l}0 . \\
2 \\
a\end{array}$ & $\begin{array}{l}0 . \\
6 \\
a\end{array}$ & $\begin{array}{l}1 . \\
6 \\
a\end{array}$ & $\begin{array}{l}1 \\
\mathrm{a}\end{array}$ & $\begin{array}{l}2 \\
a\end{array}$ \\
\hline 7 & $\begin{array}{l}2 . \\
6 \\
a\end{array}$ & $\begin{array}{l}0 . \\
7 \\
\mathrm{a}\end{array}$ & $\begin{array}{l}4 . \\
1\end{array}$ & $\begin{array}{l}0 . \\
7 \\
\mathrm{a}\end{array}$ & $\begin{array}{l}4 . \\
3\end{array}$ & $\begin{array}{l}0 . \\
3 \\
\mathrm{a}\end{array}$ & $\begin{array}{l}5 . \\
1\end{array}$ & $\begin{array}{l}0 . \\
8 \\
a\end{array}$ & $\begin{array}{l}1 . \\
3 \\
\mathrm{a}\end{array}$ & $\begin{array}{l}1 . \\
4 \\
a\end{array}$ & $\begin{array}{l}0 . \\
7 \\
\mathrm{a}\end{array}$ & $\begin{array}{l}0 . \\
9 \\
\mathrm{a}\end{array}$ & $\begin{array}{l}0 . \\
5 \\
a\end{array}$ & $\begin{array}{l}2 \\
a\end{array}$ & $\begin{array}{l}0 . \\
3 \\
\mathrm{a}\end{array}$ & $\begin{array}{l}0 . \\
2 \\
\mathrm{a}\end{array}$ & $\begin{array}{l}0 . \\
5 \\
\mathrm{a}\end{array}$ & $\begin{array}{l}1 . \\
3 \\
\mathrm{a}\end{array}$ & $\begin{array}{l}0 . \\
8 \\
a\end{array}$ & $\begin{array}{l}1 . \\
9 \\
\mathrm{a}\end{array}$ \\
\hline 8 & $\begin{array}{l}2 . \\
3 \\
\text { a }\end{array}$ & $\begin{array}{l}0 . \\
6 \\
a\end{array}$ & $\begin{array}{l}3 . \\
8 \\
a\end{array}$ & $\begin{array}{l}0 . \\
7 \\
\mathrm{a}\end{array}$ & $\begin{array}{l}3 . \\
7 \\
\mathrm{a}\end{array}$ & $\begin{array}{l}0 . \\
3 \\
\mathrm{a}\end{array}$ & $\begin{array}{l}9 . \\
3\end{array}$ & $\begin{array}{l}0 . \\
7 \\
\mathrm{a}\end{array}$ & $\begin{array}{l}1 . \\
1 \\
\mathrm{a}\end{array}$ & $\begin{array}{l}1 . \\
2 \\
\text { a }\end{array}$ & $\begin{array}{l}0 . \\
6 \\
a\end{array}$ & $\begin{array}{l}1 \\
a\end{array}$ & $\begin{array}{l}0 . \\
4 \\
\mathrm{a}\end{array}$ & $\begin{array}{l}2 . \\
8 \\
a\end{array}$ & $\begin{array}{l}0 . \\
3 \\
a\end{array}$ & $\begin{array}{l}0 . \\
5 \\
a\end{array}$ & $\begin{array}{l}0 . \\
5 \\
a\end{array}$ & $\begin{array}{l}1 . \\
7 \\
\mathrm{a}\end{array}$ & $\begin{array}{l}1 \\
\mathrm{a}\end{array}$ & $\begin{array}{l}2 . \\
7 \\
\mathrm{a}\end{array}$ \\
\hline 9 & $\begin{array}{l}2 . \\
2 \\
a\end{array}$ & $\begin{array}{l}0 . \\
5 \\
\mathrm{a}\end{array}$ & $\begin{array}{l}3 . \\
7 \\
\mathrm{a}\end{array}$ & $\begin{array}{l}0 . \\
6 \\
\mathrm{a}\end{array}$ & $\begin{array}{l}3 . \\
3 \\
\mathrm{a}\end{array}$ & $\begin{array}{l}0 . \\
3 \\
\mathrm{a}\end{array}$ & $\begin{array}{l}8 . \\
5\end{array}$ & $\begin{array}{l}0 . \\
5 \\
\mathrm{a}\end{array}$ & $\begin{array}{l}1 \\
\mathrm{a}\end{array}$ & $\begin{array}{l}1 . \\
1 \\
\mathrm{a}\end{array}$ & $\begin{array}{l}0 . \\
5 \\
a\end{array}$ & $\begin{array}{l}1 \\
a\end{array}$ & $\begin{array}{l}0 . \\
4 \\
\mathrm{a}\end{array}$ & $\begin{array}{l}2 . \\
3 \\
a\end{array}$ & $\begin{array}{l}0 . \\
5 \\
a\end{array}$ & $\begin{array}{l}0 . \\
7 \\
\mathrm{a}\end{array}$ & $\begin{array}{l}0 . \\
6 \\
a\end{array}$ & $\begin{array}{l}2 . \\
2 \\
a\end{array}$ & $\begin{array}{l}0 . \\
9 \\
\mathrm{a}\end{array}$ & $\begin{array}{l}2 . \\
3 \\
a\end{array}$ \\
\hline 10 & $\begin{array}{l}2 \\
a\end{array}$ & $\begin{array}{l}0 . \\
5 \\
a\end{array}$ & $\begin{array}{l}3 . \\
6 \\
a\end{array}$ & $\begin{array}{l}0 . \\
7 \\
\mathrm{a}\end{array}$ & $\begin{array}{l}3 \\
a\end{array}$ & $\begin{array}{l}0 . \\
3 \\
\mathrm{a}\end{array}$ & $\begin{array}{l}8 . \\
3\end{array}$ & $\begin{array}{l}0 . \\
5 \\
a\end{array}$ & $\begin{array}{l}1 \\
\mathrm{a}\end{array}$ & $\begin{array}{l}1 \\
\mathrm{a}\end{array}$ & $\begin{array}{l}0 . \\
5 \\
a\end{array}$ & $\begin{array}{l}0 . \\
9 \\
\mathrm{a}\end{array}$ & $\begin{array}{l}0 . \\
4 \\
a\end{array}$ & $\begin{array}{l}2 . \\
6 \\
a\end{array}$ & $\begin{array}{l}0 . \\
4 \\
a\end{array}$ & $\begin{array}{l}0 . \\
6 \\
a\end{array}$ & $\begin{array}{l}0 . \\
4 \\
\mathrm{a}\end{array}$ & $\begin{array}{l}2 . \\
1 \\
a\end{array}$ & $\begin{array}{l}1 \\
\mathrm{a}\end{array}$ & $\begin{array}{l}2 . \\
1 \\
a\end{array}$ \\
\hline 11 & $\begin{array}{l}1 . \\
7 \\
\mathrm{a}\end{array}$ & $\begin{array}{l}0 . \\
4 \\
\mathrm{a}\end{array}$ & $\begin{array}{l}3 . \\
1 \\
\mathrm{a}\end{array}$ & $\begin{array}{l}0 . \\
7 \\
\mathrm{a}\end{array}$ & $\begin{array}{l}3 . \\
3 \\
\mathrm{a}\end{array}$ & $\begin{array}{l}0 . \\
2 \\
\mathrm{a}\end{array}$ & $\begin{array}{l}7 . \\
6\end{array}$ & $\begin{array}{l}0 . \\
5 \\
\mathrm{a}\end{array}$ & $\begin{array}{l}0 . \\
8 \\
\mathrm{a}\end{array}$ & $\begin{array}{l}0 . \\
9 \\
\text { a }\end{array}$ & $\begin{array}{l}0 . \\
5 \\
a\end{array}$ & $\begin{array}{l}0 . \\
8 \\
a\end{array}$ & $\begin{array}{l}0 . \\
4 \\
\mathrm{a}\end{array}$ & $\begin{array}{l}2 . \\
5 \\
a\end{array}$ & $\begin{array}{l}0 . \\
5 \\
a\end{array}$ & $\begin{array}{l}0 . \\
5 \\
a\end{array}$ & $\begin{array}{l}0 . \\
5 \\
a\end{array}$ & $\begin{array}{l}2 \\
a\end{array}$ & $\begin{array}{l}0 . \\
9 \\
\mathrm{a}\end{array}$ & $\begin{array}{l}2 \\
a\end{array}$ \\
\hline 12 & $\begin{array}{l}1 . \\
6 \\
\mathrm{a}\end{array}$ & $\begin{array}{l}0 . \\
4 \\
\mathrm{a}\end{array}$ & $\begin{array}{l}2 . \\
8 \\
\text { a }\end{array}$ & $\begin{array}{l}0 . \\
7 \\
\mathrm{a}\end{array}$ & $\begin{array}{l}3 . \\
4 \\
\mathrm{a}\end{array}$ & $\begin{array}{l}0 . \\
2 \\
\mathrm{a}\end{array}$ & $\begin{array}{l}6 . \\
9\end{array}$ & $\begin{array}{l}0 . \\
6 \\
a\end{array}$ & $\begin{array}{l}0 . \\
7 \\
\mathrm{a}\end{array}$ & \begin{tabular}{|l}
0. \\
8 \\
a \\
\end{tabular} & $\begin{array}{l}0 . \\
4 \\
\mathrm{a}\end{array}$ & $\begin{array}{l}0 . \\
7 \\
\mathrm{a}\end{array}$ & $\begin{array}{l}0 . \\
3 \\
\mathrm{a}\end{array}$ & $\begin{array}{l}2 . \\
3 \\
a\end{array}$ & $\begin{array}{l}0 . \\
4 \\
a\end{array}$ & $\begin{array}{l}0 . \\
5 \\
a\end{array}$ & $\begin{array}{l}0 . \\
4 \\
a\end{array}$ & $\begin{array}{l}2 \\
a\end{array}$ & $\begin{array}{l}0 . \\
8 \\
a\end{array}$ & $\begin{array}{l}1 . \\
8 \\
a\end{array}$ \\
\hline 13 & $\begin{array}{l}1 . \\
7 \\
\end{array}$ & $\begin{array}{l}0 . \\
4\end{array}$ & $\begin{array}{l}3 . \\
1\end{array}$ & $\begin{array}{l}0 . \\
7\end{array}$ & $\begin{array}{l}3 . \\
7\end{array}$ & $\begin{array}{l}0 . \\
4 \\
\end{array}$ & $\begin{array}{l}6 . \\
5\end{array}$ & $\begin{array}{l}0 . \\
6\end{array}$ & $\begin{array}{l}0 . \\
7\end{array}$ & 0. & 0. & $\begin{array}{l}0 . \\
7\end{array}$ & $\begin{array}{l}0 . \\
3\end{array}$ & $\begin{array}{l}2 . \\
3\end{array}$ & $\begin{array}{l}0 . \\
4 \\
\end{array}$ & $\begin{array}{l}0 . \\
8\end{array}$ & $\begin{array}{l}0 . \\
5\end{array}$ & $\begin{array}{l}2 \\
\mathrm{a}\end{array}$ & $\begin{array}{l}1 \\
\mathrm{a} \\
\end{array}$ & $\begin{array}{l}1 . \\
7\end{array}$ \\
\hline
\end{tabular}




\begin{tabular}{|l|l|l|l|l|l|l|l|l|l|l|l|l|l|l|l|l|l|l|l|l|}
\hline & $\mathrm{a}$ & $\mathrm{a}$ & $\mathrm{a}$ & $\mathrm{a}$ & $\mathrm{a}$ & $\mathrm{a}$ & & $\mathrm{a}$ & $\mathrm{a}$ & $\mathrm{a}$ & $\mathrm{a}$ & $\mathrm{a}$ & $\mathrm{a}$ & $\mathrm{a}$ & $\mathrm{a}$ & $\mathrm{a}$ & $\mathrm{a}$ & & & $\mathrm{a}$ \\
\hline 14 & 1. & 0. & 2. & 0. & 3. & 0. & 6 & 0. & 0. & 0. & 0. & 0. & 0. & 2. & 0. & 0. & 0. & 1. & 1 & 1. \\
& 7 & 3 & 9 & 6 & 4 & 5 & & 5 & 7 & 8 & 4 & 7 & 3 & 1 & 4 & 7 & 6 & 8 & $\mathrm{a}$ & 6 \\
& $\mathrm{a}$ & $\mathrm{a}$ & $\mathrm{a}$ & $\mathrm{a}$ & $\mathrm{a}$ & $\mathrm{a}$ & & $\mathrm{a}$ & $\mathrm{a}$ & $\mathrm{a}$ & $\mathrm{a}$ & $\mathrm{a}$ & $\mathrm{a}$ & $\mathrm{a}$ & $\mathrm{a}$ & $\mathrm{a}$ & $\mathrm{a}$ & $\mathrm{a}$ & & $\mathrm{a}$ \\
\hline
\end{tabular}

SOURCE: Authors' computation (2016).

Alphabet "a" indicates acceptance of the null hypothesis, that is, the test is not significant KEYS:A: Dollars does not Granger cause CFA Franc

B: CFA Franc does not Granger cause dollars

C: Pounds does not Granger cause CFA Franc

D: CFA Franc does not granger cause Pounds

E: Swiss Franc does not Granger cause CFA franc

F: CFA Franc does not Granger cause Swiss Franc

G: Yen does not Granger cause CFA Franc

H: CFA Franc does not Granger cause Yen

I: Pounds does not Granger cause Dollars

J: Dollars does not Granger cause Pounds

K: Swiss Franc does not Granger cause Dollars

L: Dollars does not Granger cause Swiss Franc

M: Yen does not Granger cause Dollars

N: Dollars does not Granger cause Yen

O: Swiss Franc does not Granger cause Pounds

P: Pounds does not Granger cause Swiss Franc

Q: Yen does not Granger cause Pounds

R: Pounds does not Granger cause Yen

S: Yen does not Granger cause Swiss Franc

T: Swiss franc does not Granger cause Yen

\subsection{Implications of findings}

The Weak Form Efficiency test deployed the Autocorrelation Function test and the Unit Root tests of Augmented Dickey Fuller and Phillips-Perron. The Autocorrelation test at level concluded rejection of the null hypothesis that the series autocorrelation equals zero. $\left(P_{k}=0\right)$. This implied that the series were non-stationary at level. However at first difference 
the Autocorrelation test accepted the null hypothesis, that is, the series became stationary at first difference. This was in line with the properties of the Random Walk Model. Similarly the unit root tests accepted the null hypothesis of presence of Unit Root at level and rejected same at first difference, this meant that the series were non-stationary at level but became stationary at first difference.

The fact that the series were non-stationary at level meant that past values could not be used to predict present value of exchange rate. This is a necessary condition for weak form efficiency. The study therefore concluded that exchange rates series in Nigeria within the sample period were weak form efficient. All past information were reflected in the present price, the exchange rates were random in response to economic climate and no market player could discover an exploitable trend to outperform the market consistently. Wickremasinghe (2004) arrived at similar conclusions in the case of Sri Lanka.

The Semi Strong form efficiency test deployed the Johansen cointegration test and the Granger causality tests. In the Johansen cointegration test, the researcher tested the hypothesis that the selected pairs were not cointegrated. In all the cases, the test accepted the null hypothesis and thus statistically not significant. This indicated that the selected pairs did not have long run equilibrium relationship. Kasman and Ayhan (2007) reached similar conclusion. In each pair one exchange rate could be used to predict the value of the other exchange rate. This was a necessary condition for semi strong form efficiency. Similarly the Granger Causality tests accepted the null hypothesis of no causal relationship between selected pairs that is the test was not significant. The study concluded that the exchange rates in Nigeria within the sample period were semi strong form efficient. All publicly available information were reflected in the values of all exchange rates simultaneously and one exchange rate could not be used to predict the value of the other.

Lastly, in the unit root tests, the significantly higher Coefficient of Determination $\left(\mathrm{R}^{2)}\right.$ of all the exchange rate series under the assumption of Random Walk with intercept and deterministic trend led to the conclusion that the exchange rate series in Nigeria within the sample period followed the Random Walk Model with drift and deterministic trend

\subsection{Summary and Conclusion}

Foreign exchange market in Nigeria within the study's sample period was efficient in weak and semi strong forms, consequently, the private participants should concentrate on hedging foreign exchange risks by actively participating in forward exchange transactions since exploitable profit opportunities were absent in the market. Regulatory policies should therefore be geared towards ensuring market liquidity and depth of the forward market. The government should take rates determined in the foreign exchange market as the equilibrium, and if domestic currency appreciation is desired, policies that will improve exogenous factors determining exchange rates should be pursued. Specifically the following policy recommendations are suggested. 
First, the flexible exchange regime adopted in Nigeria should be more of the clean float, as at December 2015, the Nigerian exchange rate policy was more of the filthy float. Heavy interventions by the Central Bank of Nigeria to keep the Dollar rates within target bands were noticed even in the face of dwindling oil inflows. Arbitrage premium widened which encouraged round tripping and rent seeking. The floating exchange regime in operation in Nigeria should be more liberalized and move towards a clean float, this will engender automatic clearance of deficit or surplus in the market, protection of external reserve and ensure monetary policy independence. Second, the depth of the foreign exchange forward market should be improved, presently the Forward Exchange market in Nigeria is none existing, partakers in Foreign Exchange transaction were exposed without hedging options, key participants in the Foreign exchange market should be encouraged to develop, buy and sell hedging products like Futures, Forward and Options for protection against risk.

Third, Non-oil Exports should be promoted and diversified the main Foreign Exchange earner in Nigeria is oil export, this stood at 67.5 per cent of total federally collected revenue as at December 2014 (Central bank of Nigeria annual Report, 2014), and this heavy dependence on oil exports exposed the Nigerian economy to risk brought about by volatility in the oil market. Encouraging agro based exports through fiscal incentives, low interest loans and subsidized agriculture inputs should be vigorously pursued.

Fourth, restriction of consumer goods importation should be pursued progressively, capital goods and raw material imports should be substituted as much as feasible with locally available alternatives. As at December 2014, 43.2 per cent of total imports were consumer goods (Central Bank of Nigeria, 2014), this trend should be reversed, consumption of locally available consumer goods should be encouraged through imposition of high tariffs on imported consumer goods, this would lead to increase in domestic aggregate output and employment.

Fifth, Capital Imports should be encouraged, investment by foreigners in Nigeria should be encouraged, this may be in the form of Portfolio Investment or Foreign Direct Investment, effect of cross border movements in finance has overtaken effects of trade movements on exchange rate determination due to globalization, as such policies that will improve domestic security, provide access to domestic and regional markets and provide critical infrastructure that will drive economic development should be pursued. A corollary to this is to discourage Capital Flight, Nigeria being a developing economy should attract Capital Imports and reduce Capital Flight to the barest minimum. Tax incentives, establishment of free trade zones, unrestricted opportunity to repatriate profits and relaxed minimum legal requirement for startups will achieve reduction of capital flight in Nigeria.

Sixth, the Arbitrage Margin which is the difference in rates between the official exchange rates and the parallel market rates should be reduced. Companies that earn foreign currency should have unfettered right of use and of which market to patronize when converting the foreign currency to domestic currency equivalents, in addition, the dollarization of the domestic economy should be halted through legislation, transactions in foreign currency should be through accounts kept with financial institutions, these suggestions would engender improved surveillance of the financial system, improve 
market liquidity, Arbitrage Margin will decay and the incentive for Round Tripping and Rent Seeking will be eroded.

Lastly there should be Improved Monitoring by the Central Bank of Nigeria. Systems that will promptly detect sharp practices of market participants should be used in the market and erring participants should be severely sanctioned to act as deterrent. Market participants should be required to provide market information and analyses that are necessary inputs for the development of the system.

\section{REFERENCES}

Aron, J. (1997). Foreign Exchange Market Efficiency Tests in South Africa. Centre for the Study of African Economies, Department of Economics, Oxford University Press Southern Africa ( Pty) Ltd.

Ayodele, J. (1988). Exchange Rate Devaluation and the Nigerian External Accounts, a Flow of Funds Approach. The Nigerian journal of Economic and social Studies, 30(2), 149-165.

Baillie, R.T., \& Bollerslev, T. (1989). Common Stochastic Trends in a System of Exchange Rates. The Journal of Finance, 44(1), 167-181.

Christos Kollias, Nikolaos Mylonidis \& Suzanna-Maria Paleologu, (2012). The Nexus between Exchange Rates and Stock Markets: Evidence from the Euro-dollar Rate and Composite European Stock indices Using Rolling Analysis. Journal of Economics and Finance, 36, 36-147.

Dooley, M.P., \& Shafer, J. (1976). Analysis of Short Run Exchange Rate Behaviour : March 1973September 1975. International Finance Discussion Papers no 76, Washington, D.C. Federal Reserve System.

Fama, E. (1970). Efficient Capital Markets, a Review of Theory and Empirical works. Journal of Finance, 25,383-417.

Fama, E.F. (1965). The Behaviour of Stock Market Prices. Journal of Business,38, 34-105.

Gujarati, D.N. (2013). Basic Econometrics. U.S.A: Mc Graw-Hill Companies Inc.

Ibrahim, J., Long, Y., Ab. Ghani, H., \& Mohd Salleh, S. (2011). Weak Form Efficiency of $\quad$ Foreign Exchange Market in the Organisation for Economic Cooperation and Development Countries : Unit Root Test. International Journal of Business and Management, 6(6), 55-65.

Kang, H. (2008). The Cointegration Relationships among G-7 Foreign Exchange Rates. International Review of Financial Analysis, 115, 53-74.

Kasman, A., \& Ayhan, D. (2007). Foreign Exchange Reserves and Exchange Rates in Turkey Structural Breaks, Unit Roots and Co-Integration . Economic Modeling, 25, 83-92.

Kellard, N. (2006). On the Robustness of Cointegration Tests when Assessing Market Efficiency. Finance Research letters, 3, 57-64.

Kim, J.K., \& Ratti, R. A. (2006). Economic Activity, Foreign Exchange Rate, and the Interest Rate during Asian Crisis. Journal of Policy Modelling, 28, 387-402. 
Krishnaveni, P., Varadaraj, S., \& Karthika, P. (2014). An Empirical Evaluation of Foreign Market Efficiency of Chfjpy Currency Pair. Indian Journal of Research, 3(11), 113-127.

Lee, H., \& Sodoikhuu, K. (2012). Efficiency Tests in Foreign Exchange Market. International Journal of Economics and Financial Issues, 2(2), 216-224.

Levich, R.M., \& Lee, R.T. (1993). The Significance of Technical Trading-Rule Profits in the Foreign Exchange Market : A Bootstrap Approach. Journal of International Money and Finance, 12(5), 451474.

Mabakeng, M.E.P., \& Sheefani, J.P.S. ( 2014). Investigating the Semi Strong Efficiency in Namibia's Foreign Exchange Market. Global Journal of Contemporary Research in Accounting, Auditing and Business Ethics, 1(3), 168-180.

Ogun, o. (1985). Devaluation and the Nigerian Economy. The Nigerian journal of Economic and social Studies, 27(2), 163-178.

Oloyede, J.A. (1999). Exchange Market Efficiency: A Review of Doctrinal and Empirical Perspectives. Review of Growth and Change, 2(2), 46-53.

Reddy, Y.V., \& Sebastin, A. (2008). Interaction between Forex and Stock Market in India: An Entropy Approach. Vikapla, 33(4), 27-45.

Wickremasinghe, G.B. (2004). Efficiency of Foreign Exchange Markets: A Developing Country Perspective. ABERU Discussion Paper 3. 